\title{
運転者の規制標識認知に影響する要因に関する研究*
}

\section{Factors Affecting Driver Recognition of Regulatory Signs}

\author{
三井達郎** \\ 矢野伸裕 ${ }^{* * *}$ \\ 木平真**** \\ Tatsuro MITSUI Nobuhiro YANO Makoto KIHIRA
}

\section{1.はじめに}

道路標識は、交通規制、前方の危険性等の安全運転に 不可欠な情報を道路利用者の視覚のみに頼って提供する 施設である。したがって、物理的に見えることが道路標 識の満たすべき最低条件であり、標識板は樹木等に遮蔽 されてはならず、反射性能の劣化や退色によって標識内 容が判読できないようなものであってはならない。しか し、物理的に見えるだけで充分というわけではない。な ぜなら、運転者は、実際に目に映る情報を必ずしもすべ て認知しているわけではなく、注意すること、すなわち、 ある情報を自覚したと意識してはじめてその情報が運転 者に伝わるからである ${ }^{1}$ 。

道路標識の設計において運転者の注意に配慮すること は、特に規制標識の設置の際には極めて重要である。こ の理由は、規制標識は案内標識と異なり一瞥しただけで その内容が容易に把握できる場合が多いので、判読でき るか否かよりも標識に気づくか否かによってその標識の 有效性が大きく左右されると考えられるからである。し たがって、規制標識の設置に当たっては、物理的に見え ることはもちろん、できる限り運転者に注意されやすい ような方法、すなわち認知されやすいような方法で設置 されることが必要となる。

以上の背景を踏まえ、本研究では、規制標識の認知し やすさ (Conspicuity) に影響する要因を調査し、規制標 識のもつ情報を運転者に的確に伝えるための設置方法に 関して知見を得ることを目的とする。具体的には、規制 標識の認知しやすさに影響する要因として、運転者の標 識に対する注意度、標識の設置位置、道路環境等を取り 上げ、実道路上での走行実験を通して各要因が規制標識 の認知しやすさに及ぼす影響を明らかにする。

\section{2. 従来の研究}

上述したように、標識の持つ情報を運転者に伝える

\footnotetext{
* キーワード : 交通管理、交通安全

** 正会員 工修 科学警察研究所交通規制研究室

*** 非会貝 文修 科学警察研究所交通規制研究室

$* * * *$ 非会員 工修 科学警察研究所車両運転研究室 （干277-0882 千葉県柏市柏の葉 6-3·1 TEL:0471-35-8001
} FAX:0471-33-9187)
ためには 2 つの機能が要求される。すなわち標識に気づ くことと表示内容が読みとれることである。しかしなが ら、従来の標識に関する研究の多くは表示内容の読みと りやすさを主に扱ったものであり、標識の気づきやすさ を調査した研究は比較的少ない。主なものを以下に示す。

蓮花 ${ }^{2)}$ は、スクリーンに運転場面を投影した室内実験 によって視覚的注意を調べている。言語報告法によって 注視状況を口頭報告させた結果、標識標示類の報告数は 全報告の $20.3 \%$ あるとしている。この研究では、運転 時の視覚的注意の一般的傾向を調べることをねらいとし ているので、標識の設置位置等と注意状況の関連性につ いては触れていない。

Hughes と Cole ${ }^{3) ~ \text { ) }}$ は交通安全施設の気づきやすさに関 する一連の研究を行っている。彼らは、目標物の気づき やすさは、観察者の注意が目標物に向けられているか否 かによって異なると考え、注意の仕方と目標物認知との 関係を調べた。その結果、規制標識の認知率は交通安全 施設に注意を向けないで運転している場合で $14.0 \%$ 、注 意を向けている場合で $67.6 \%$ あり、規制標識の中では STOP標識と Give Way 標識で認知率が最も高いと報告し ている ${ }^{3)}$ 。また、実際の道路上に実験用として設置した ディスクターゲット（様々な色、大きさをもつ円形の目 標物）の認知率を調べた結果から、認知率は進行方向と 対象物のなす角度によって最も影響されることを示して いる ${ }^{4)}$ 。さらに、道路環境別の交通安全施設の認知率を

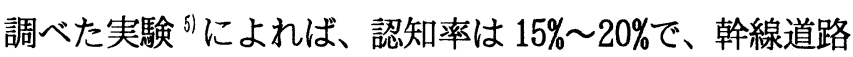
で高くショッピングセンターに面した道路で低いという 結果が得られている。これらの研究では、標識に限らず 様々な視対象の認知状況を調べることをねらいとしてお り、標識の認知率に影響する要因については詳細な検討 を行っていない。

Johansson $5^{61,7)}$ は、道路標識の有効性を運転者の標識 に対する認知度の観点から検討している。実際の道路上 に実験用の標識を設置し、そこを通過した運転者を停止 させた上で標識の認知状況に関する質問を行った。その 結果、標識認知率はどのような標識に対しても $100 \%$ とは ならず、また、標識の見やすさや交通量は標識認知率に 大きな影響を及ぼさないと報告している。この研究でも、 標識の設置位置に関する詳細な考察はなされていない。

以上述べたように、過去の標識の認知率に着目した研 究は、いずれもが認知率がどの程度か、を調べることを 
主たるねらいとしており、本研究のように標識の設置方 法改善の観点から標識認知率とその影響要因を検討して いる研究は見られない。

\section{3. 実験方法}

\section{（1）実験コース及び被験者}

千葉県柏市の実際の道路上に全長 $14 \mathrm{~km}$ の実験コース を設定し、走行実験を行った。実験コースは片側 1 車線 の 2 車線道路であり、住宅地内の道路(道路 a)、郊外の 広幅員道路(道路 b) 、地方部主要道路 (道路 $\mathrm{c}$ ) 加構成 されている。実験コースの状況を図 1 および表 1 に示す。 実験コースには 147 本の標識が設置されている。表 2 に 実験コース上の標識の種類を示す。同表で、1 本の標識 に複数の標識板が併設されている場合の標識種類の分類 は、最上位に取り付けてある標識板に基づいて行った。 実験コース上の道路標示に関しては、最高速度標示が道 路 aに 4 箇所、道路 cに 4 箇所設置されている。また、 大部分の区間(道路 $\mathrm{a}$ の一部および道路 $\mathrm{b}$ の一部を除く) には「追い越しのための右側部分はみ出し通行禁止」を 示す黄色の中央線が設置されている。なお、駐車禁止標 示は全区間にわたって設置されていない。

被験者は 65 歳以上の高齢者 16 名（平均年齢 68 歳）、 30 歳未満の若年者 15 名 (平均年齢 23 歳) の計 31 名で ある。被験者はすべて男性で実験コースの運転は今回が 最初である。

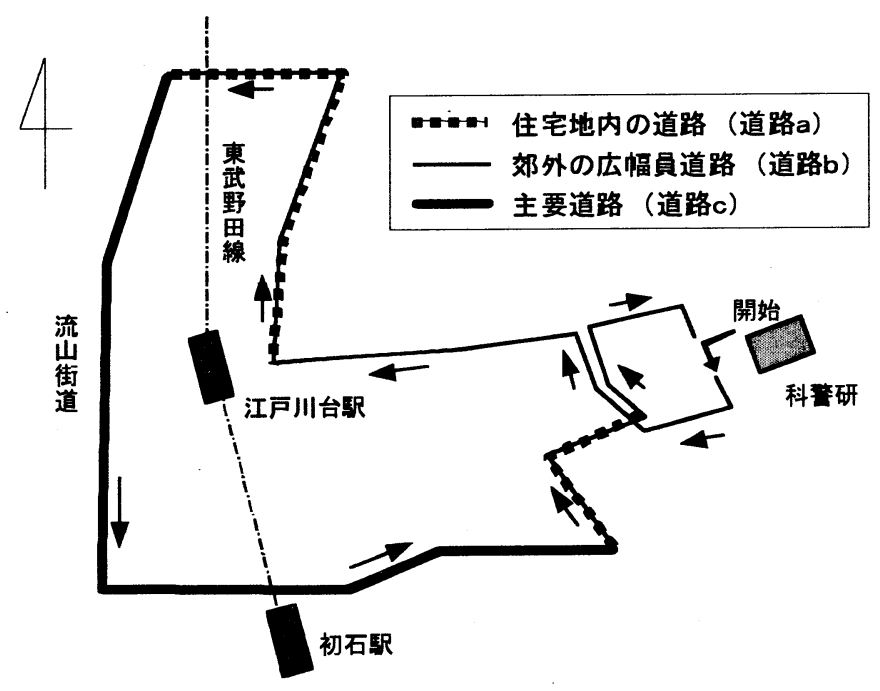

図 1 実験コース

\section{（2）言語報告法について}

運転中に何を見たかを調べるために言語報告法 ${ }^{2) ~ j) ~}$ 用いた。この方法は、注視している対象を次々と口頭で 報告するもので、蓮花はアイカメラを用いた方法 ${ }^{8)}$ と比 較した言語報告法の特徴を以下のように整理している ${ }^{2)}$ 。
表 1 実験コースの概要

\begin{tabular}{|c|c|c|c|c|c|c|}
\hline タイプ & $\begin{array}{l}\text { 邁対向 } \\
\text { 車台数注) } \\
\text { (台/時) }\end{array}$ & \begin{tabular}{|l} 
車道幅 \\
貝 \\
$(\mathrm{m})$ \\
\end{tabular} & \begin{tabular}{|c|} 
規制速度度 \\
$(\mathrm{km} /$ 時)
\end{tabular} & $\begin{array}{c}\text { 区間長 } \\
(\mathrm{m})\end{array}$ & $\begin{array}{l}\text { 標識設置 } \\
\text { 数 } \\
(\text { 本/100m) } \\
\end{array}$ & 道路の状況 \\
\hline 道路a & 173 & 6 & 30 & 3530 & 1.08 & $\begin{array}{l}\text { 住宅地内の道路、自 } \\
\text { 動車交通量は極めて } \\
\text { 少ない }\end{array}$ \\
\hline 道路b & 674 & 9 & 50 & 4070 & 1.15 & $\begin{array}{l}\text { 郊外の広幅員道路、 } \\
\text { 沿道は街路樹、自動 } \\
\text { 車交通量は少ない }\end{array}$ \\
\hline 道路 & 1099 & 7 & 40 & 6270 & 1.12 & $\begin{array}{l}\text { 地方部主要道路、沿 } \\
\text { 道は建物、自動車交 } \\
\text { 通量は多い }\end{array}$ \\
\hline
\end{tabular}

注) 走行中に出会った対向車の台数 (平均値)

\section{表 2 実験コース上の標識の種類と本数}

\begin{tabular}{|c|c|c|}
\hline 橒識の種類 & $\begin{array}{c}\text { 標識令 } \\
\text { 番号 }\end{array}$ & 本数 \\
\hline 高速入口の予告 & 104 & 1 \\
\hline 方面及ひ方向の予告 & 108-2A & 1 \\
\hline 警戒橾識 & 200番台 & 10 \\
\hline 大型货物通行止め & 305 & 3 \\
\hline 指定方向外進行禁止 & $311 \mathrm{~A} \sim \mathrm{F}$ & 17 \\
\hline はみ出し禁止 & 314 & 20 \\
\hline 駐車禁止 & 316 & 25 \\
\hline 最高速度 & 323 & 27 \\
\hline 一時停止 & 330 & 2 \\
\hline 横断歩道 & $407-A, B$ & 41 \\
\hline 計 & & 147 \\
\hline
\end{tabular}

a)「何を見ているか」について、アイカメラ法に比べて より具体的に把握できる。例えば、アイカメラで道路 上に注視点が存在している場合でも、言語報告では 「前方」「中央線」「対向車線」などの具体的な視対 象が報告される。

b) 言語報告法では、単に注視している対象物を把握でき るに留まらず、運転者が「どのように」見ているかに 関する情報を得ることができる。例えば、交差する道 路や信号を漫然と見ている場合と、「道路から歩行者 の飛び出しがないかどうか」「信号が青かどうか」を 予測・確認している場合では報告内容が異なる。

c) 注視の方向、範囲、頻度、持続時間のような数量的解 析を可能とするデー夕を集めにくい。

d) 注視対象の「言語化」に伴う次のような歪曲が存在す る。(1)注視対象の一部しか報告されない。(2)言語報告 を行うことによって注視の仕方が変化する可能性が ある。(3)対象によって報告が容易なものと困難なもの がある。

上記の a),b)は言語報告法の長所であり、c),d)は短所 である。蓮花 ${ }^{21}$ が述べているように、言語報告法では、 報告される対象は注視された対象のうちの一部であると いう問題点があるにせよ、それは全注視対象からのラン ダムなサンプリングというよりは、その時々で被験者が 重要だと感じ、強い印象を持ち、必要だと感じた対象が 報告されると考えることができる。

また、注視の仕方が変化するという短所は、運転者が 
重要と感じて注視した対象物を「報告」しなければなら ないためその対象物を通常よりも長く注視することに起 因すると考えられる。よって、運転者にとってそれほど 重要と感じない対象物は言語報告によって見落とされる ことがあり得るが、重要なものは言語報告を行っても見 落とされる可能性は少ないと推察される。

規制標識に要求されるのは、まさに、運転者が重要で あり必要と感じながら視認されることであるから、本研 究では、標識の認知状況の測定に言語報告法を用いるこ ととした。

なお、注視対象の言語化に伴うもう 1 つの短所である 「報告が容易なものと困難なものがある」という点につ いては、今回の実験で対象としている道路標識は報告が 比較的容易であるので、報告のしやすさによるバイアス は無視できるものと考えた。

\section{（3）実験手順}

被験者は、運転中の注意の仕方によって二群に分けた。 第 1 群は、標識に限らず見たものすべてを口頭報告する ように教示した通常運転グループで、被験者数は 23 名

（高秢者 12 名、若年者 11 名）である。第 2 群は、標識 に注意して運転し、見つけた標識のみを口頭報告するよ うに教示した標識注意運転グループで、被験者数は 8 名 （高歯者 4 名、若年者 4 名）である。被験者を二群に分 けた理由は、標識への気づきやすさは、標識に特別の注 意を払わないで普通に運転する場合と、標識を探しなが ら運転する場合（交差点で右折したいときに右折禁止で ないことを確かめたり、速度違反をしていないかどうか を確認する場合等）では、異なると考えたからである。 第 1 群は前者に相当し、第 2 群は後者に相当する。また、 今回の実験では、被験者数を標識注意運転よりも通常運 転で多く配分したがこの理由は次の通りである。通常運 転では被験者に対して注意すべき対象を特定しておらず、 被験者が何を報告するかは個々の被験者に任せられてい る。一方、標識注意運転では、見つけた標識のみを報告 するように指示しているため、被験者が遂行すべき課題 は通常運転に比べてはるかに単純である。よって、標識 認知状況の個人差は、報告の自由度が高い通常運転の方 が、報告内容が決まっている標識注意運転よりも大きい と考えられる。したがって、運転方法別の平均的標識認 知率を正確に知るためには、通常運転の被験者数を標識 注意運転よりも多くするのが適当と考えた。

実験に先だって、まず、各被験者への実験方法の説明 を行った。具体的には、通常運転グループに対しては「普 段通りに車を運転しながら、あなたが見たものをすべて 口に出して言ってみて下さい」という旨の説明を行い、 標識注意運転グループに対しては「道路標識に注意して 運転し、道路標識を見つけた時はそれをすべてロに出し て言ってみて下さい」という旨の説明を行った。説明の
際には、実際に言語報告を行っている状況が記録された ビデオを視聴させ言語報告法の具体的内容を被験者に理 解されやすいように配慮した。

説明の後、運転席から前方を撮影した無音声のビデオ 画像を見ながら言語報告法の練習を行った。被験者には、 画面を見ながら実際に言語報告の発声するように指示し、 言語報告を会得させた。

走行実験中は、被験者の頭部に取り付けた小型ビデオ カメラで前方を撮影すると同時に被験者の報告内容を録 音した。実験時の走行速度については、「普段どおりの運 転をして下さい」と指示した。おおよその速度は、道路 $\mathrm{a}$ で $40 \mathrm{~km} \sim 50 \mathrm{~km} / \mathrm{h}$ 、道路 bで $50 \mathrm{~km} \sim 60 \mathrm{~km} / \mathrm{h}$ 、 区間 c で $50 \mathrm{~km}$ 〜 $60 \mathrm{~km} / \mathrm{h}$ であった。実験は平日の日中に普通乗用車を用 いて行った。

\section{（4）実験データの整理}

走行実験終了後、ビデオに記録した前方画像と被験者 の報告内容、及びあらかじめ現地踏査によって調査して おいた標識属性（種類、設置位置、設置方式等）を照ら し合わせることにより、個々の標識が認知されたか否か を判断し、標識認知率を算出した。そして、実験コース 上の 147 本の標識について、標識属性と認知率の関連性 を調べた。(図 1 の実験コースには一部重複区間がある が、この区間では最初の走行時のみを分析対象とした。)

ところで、本実騟のように運転者に特別な負荷を与え る実験では、被験者の慣れや疲れが実験結果に影響する ことが考えられる。本実験では実験終了後、被験者に対 して実験全般に関する感想を聞いたが、「後半慣れた」と か「後半疲れた」といった感想は皆無であった。よって、 以下の分析では、被験者の慣れや疲れの影響については 特に勘案しなかった。

\section{4. 結果}

\section{（1）運転中の注意パターン別の認知率}

図 2 は、全標識を対象として通常運転と標識注意運転 別の標識認知率を年齢群別に示した図である。ここで認 知率とは、標識を視認できる全機会数（被験者数 $\times$ 対象 とする標識の本数）に占める実際に認知した回数の割合 を示す。例えば、図2で通常運転時における高齢者の認 知率が $16.2 \%$ となっているが、これは、標識を視認でき る 1,764 回の機会数 (12 名の被験者がそれぞれ 147 本の 標識の側方を通過したのであるから、視認機会数は延べ $12 \times 147=1,764$ 回となる) のうち、286 回(16.2\%)で認知 したことを意味する。

図 2 より、通常運転では、標識認知率は 16\%〜 18\%と低 い值となっているが、この結果は、Hughes と $\mathrm{Cole}^{3 /}$ の研 究結果とほぼ一致する。一方、標識注意運転では認知率 が 85\%以上とかなり高くなっている。これらの結果は、 


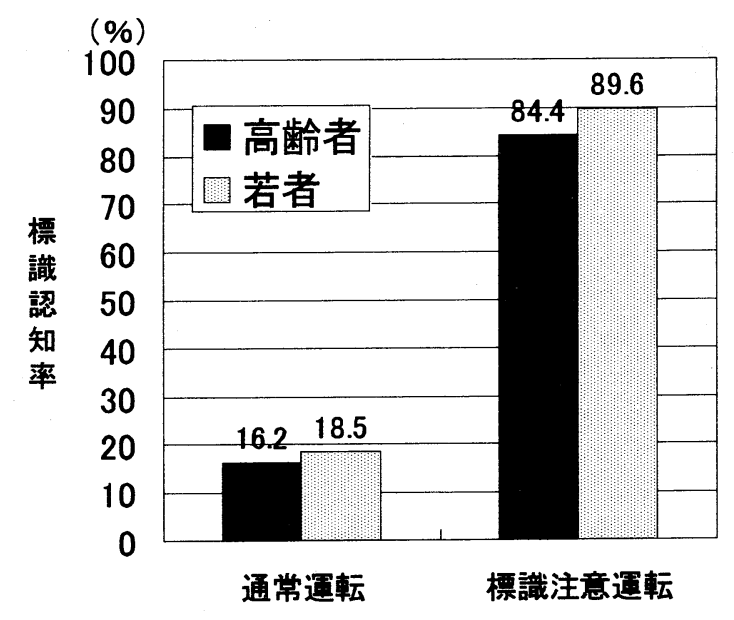

図2 運転中の注意パターン別の標識認知率

運転者が標識に特段の注意を払わないで運転している場 合には比較的標識に気づきにくいが、標識に注意して運 転すれば大部分の標識に気づくことを意味する。高齡者 と若年者の比較では、若年者より高齢者の方がわずかで はあるが認知率が低くなっているものの、両者の間に顕 著な差は見られない。

\section{(2) 標識の種類別の認知率}

図3に、標識の種類別の認知率を示す。通常運転では、 高齢者、若年者ともに最高速度標識で認知率が比較的高 く、指定方向外進行禁止、警戒標識で低くなっているこ とがわかる。指定方向外進行禁止標識の認知率が低い理 由の 1 つとして、この標識の設置位置が交差点の直前で ある点が指摘できる。すなわち、一般に交差点直前では、 対向右左折車や横断歩行者など注意すべき対象が単路部 に比べて多いために、標識に対する注意が相対的に低下 することが考えられる。

標識注意運転では、特に警戒標識で認知率が低いが、 この理由は、実験コース上の警戒標識の中には、退色や 街路樹等による遮蔽のため、極めて認知しにくいものが 少数ではあるが存在したことによると推察される。なお、 デー夕分析では、このような標識を除外することも考え られるが、本研究の主対象である規制標識には退色や遮 蔽のある標識が見られなかったこと、及び本研究では実 際の道路上に存在しているすべての標識に対する一般的 な認知状況を調べることをねらいの1つとしていること から、退色节遮蔽されている標識を含めたすべてに標識 を分析対象としている。

\section{（3）高齢者と若年者別の認知率}

図4、図 5は、個々の標識に着目したときの標識認知 率を高齢者と若年者で比較した結果を示す。図中の○の 大きさと数字は標識の本数であり（例えば図 4 で高齡者 と若年者の標識認知率がともに 0 である標識は 26 本で

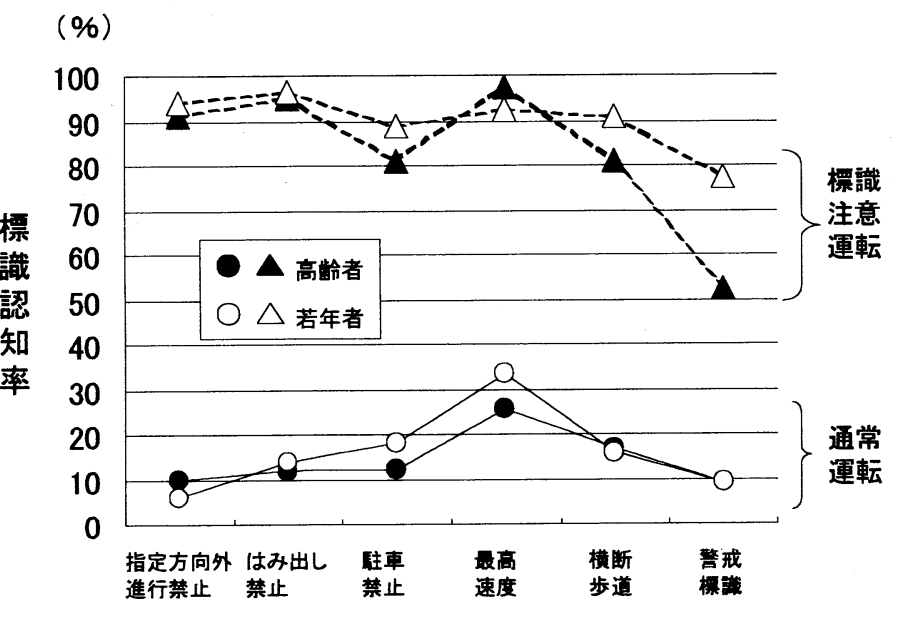

図 3 標識の種類別の認知率

あることを意味する)、斜め線は、高齢者と若年者の標識 認知率が等しい線を示す。

図4は、通常運転の場合である。全体的には、斜め線 の周辺、特に左下に標識が集まっていることがわかる。 このことから、通常運転の場合、大部分の標識で、高齢 者と若年者の標識認知率はともに低いと言える。

図 5 は、標識注意運転の場合である。斜め線の周辺に 集まっていることは図 4 と同様であるが、図5では、右 上に標識が集中していることがわかる。すなわち、標識 注意運転では、通常運転と異なり、大部分の標識で高齢 者、若年者ともに標識認知率が高くなっている。

高齢者と若年者の比較では、図4、図 5 ともに斜め線 の周辺部分の標識本数が多いことから、個別の標識別に みても高齢者と若年者の認知率はほぼ同様とみなせる。

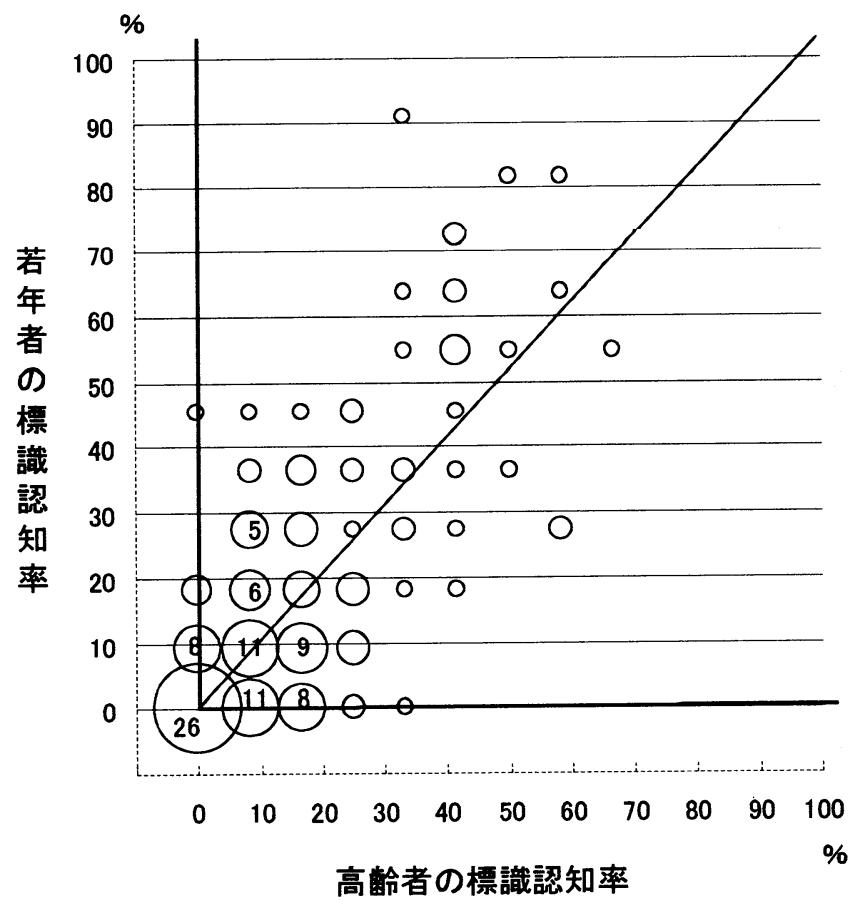

図4 高齢者と若年者の標識認知率の比較-通常運転 


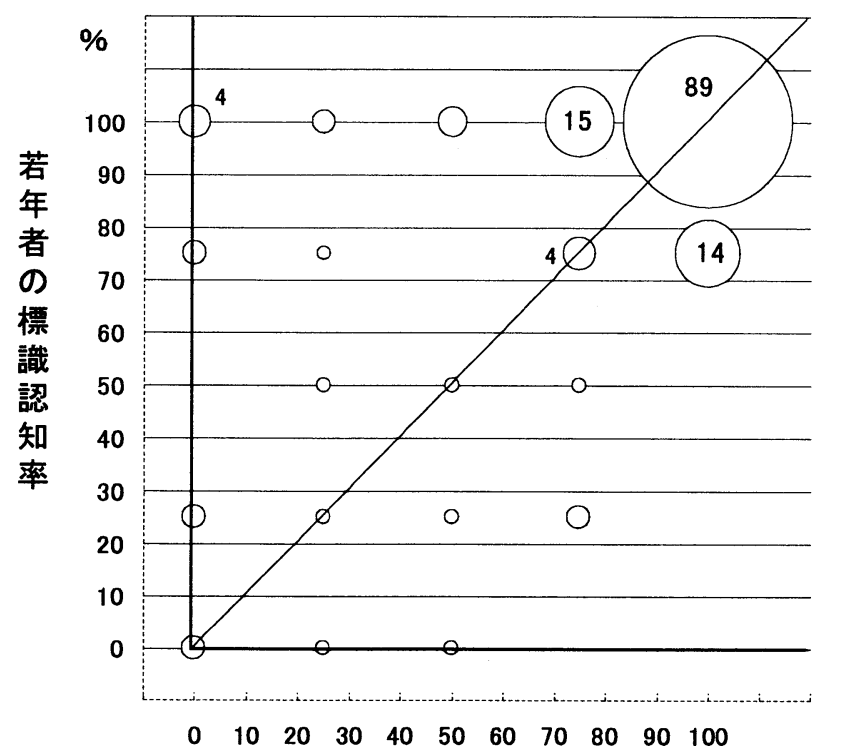

高齢者の標識認知率％

図 5 高齢者と若年者の標識認知率の比較-標識注意運転

しかしながら、標識注意運転（図5）では、若年者の認 知率が 100\%や 75\%であるにもかかわらず高齢者に認知率 が $0 \%$ あるる標識が少数ではあるが存在する。これらは、 表面が劣化した警戒標識や道路右側に設置されたオーバ ーハング標識である。

\section{（4）標識の設置条件と認知率の関係}

前述したように標識の種類は認知率に影響するが、ど の標識を用いるかは認知のしやすさではなく、交通規制 など交通管理上の必要性から決定されるものである。し たがって、以下では、設置すべき標識の種類が特定され ているときに、その標識を認知しやすくためにはどのよ うな方法で設置すべきか、という観点から標識の設置条 件と認知率の関係を検討する。ここで検討する標識は、 設置本数が 20 本以上の最高速度標識、駐車禁止標識、は み出し禁止標識、横断歩道標識の 4 種類とした。各標識 の設置条件別本数を表 3 に示す。また、高齢者と若年者 で認知傾向に顕著な差はみられなかったので、両者を一 括して分析した。

\section{表 3 設置条件別の標識本数}

\begin{tabular}{|c|c|c|c|c|c|c|c|}
\hline & 設置 & & & 賈位置 & & 票識枚数 & \\
\hline 標識種類 & 路側式 & ハング & 左側 & 右側 & 1 枚 & 2 枚 & 3枚 \\
\hline 最高速度 & 20 & 7 & 27 & W & & $\mid \frac{17}{17}$ & \\
\hline 駐車禁止 & $\overline{14}$ & 11 & 23 & $\overline{2}$ & 25 & 0 & $\overline{0}$ \\
\hline はみ出し禁止 & 18 & 2 & 20 & 0 & 3 & 17 & 0 \\
\hline 横断歩道 & 21 & 20 & 29 & 12 & 39 & 2 & 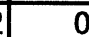 \\
\hline
\end{tabular}

（a）標識の設置方式と認知率

図6に路側式とオーバーハング式の認知率を示す。通 常運転の場合をみると、いずれの標識も路側標識に比べ てオーバーハング式の認知率が高いことがわかる。オー バーハング式は、通常、大型標識（標準サイズの 1.5〜2 倍）が用いられ、しかも走行車線の真上に設置されるこ とから、一般に見やすいことが予測されていた。本結果 からオーバーハング式の効果が実証され、オーバーハン グ方式は路側式に比べて 10 ポイント程度認知率が高い ことが明らかとなった。なお、標識注意運転では、オー バーハング式と路側式の認知率はいずれも高く、両者間 に明確な差はみられない。

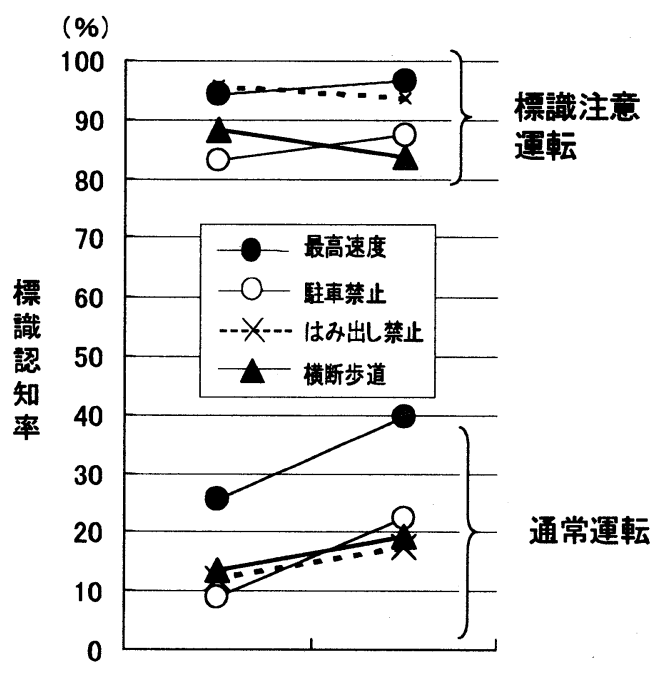

路側式 オーバーハング式

設置方式

\section{図 6 設置方式別の標識認知率}

\section{（b）標識の設置位置と認知率}

標識は道路の左側に設置するのが原則であるが、対向 車に向けた標識板の背面を利用して右側に設置される場 合も少なくない。そこで、道路の左側の標識と右側の標 識の認知率を調べた。右側に設置されている標識が実験 コース上に存在したのは駐車禁止標識と横断歩道標識の みであった。そこで、これら 2 種類の標識について、左 右別の認知率を調べた。結果を図 7 に示す。

通常運転、標識注意運転ともに右側に設置した標識の 認知率は低く、特に、標識注意運転の認知率の低下が著 しい。この理由の 1 つとして、道路の左側を走行する運 転者にとっては、対向車線を挟んでさらに右側にある標 識は視野の限界付近に位置することになり、発見しにく いことが考えられる。

以上の結果から、道路の右側に標識を設置することは 可能な限り避けることが望ましいと言える。 


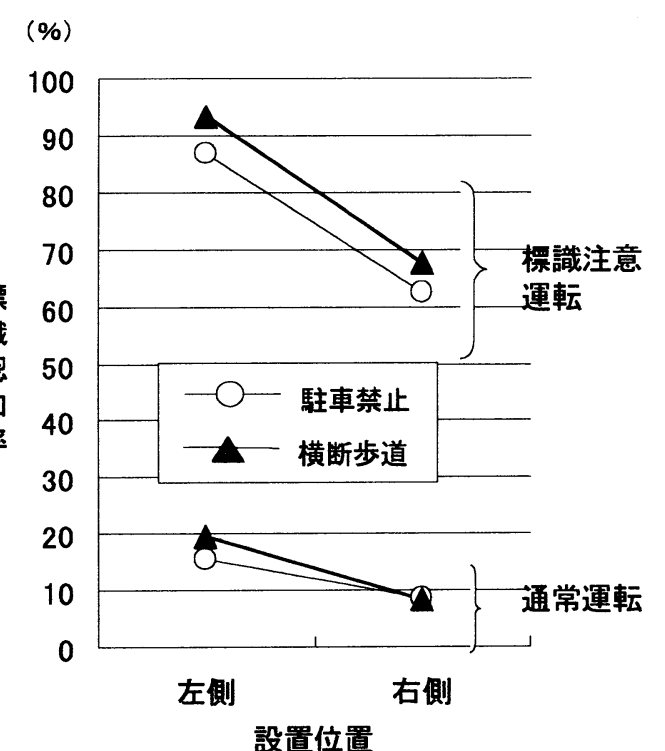

図 7 標識の設置位置別の認知率

\section{（c）設置枚数別の標識認知率}

図8に、設置枚数（1 本の標識柱に設置されている標 識板の枚数）別の標識認知率を示す。通常運転、標識注 意運転ともに、最高速度標識およびはみ出し禁止標識で は、標識枚数が多くなるにつれて認知率が低下する傾向 があるが、横断歩道標識については、標識板が 1 枚の場 合に比べて 2 枚の場合の方が認知率が高くなっている。 すなわち、標識枚数と認知率の間に一貫した関連性は見 られない。

\section{(d) 標識の横方向位置と認知率}

図 9 は、左側に設置された路側標識を対象として、標 識 1 本ごとに、横方向距離(標識柱と実験車走行車線中央 との道路横断面方向の距離) と通常運転時の認知率の関 係を示した図である。同図中に示した標識の種類別の回 滞直線は、いずれも右下がりとなっており、標識が車線 中央から離れるにしたがって認知率が低下する傾向が伺 える。しかしながら、表4に示すように、横方向距離と 認知率の相関係数はすべての標識で極めて低い值に留ま っている。したがって、路側標識の横方向距離は標識認 知率に大きな影響を及ぼさないと言える。

なお、標識注意運転については、図 $5 に$ 示したように 認知率の高い標識が非常に多く、横方向位置と認知率の 間に明確な関連性を見出すことはできなかった。

\section{（e）道路交通環境亡認知率}

標識設置場所の道路交通環境と認知率の関係を調べる ことは、設置すべき規制標識の種類と道路区間が特定さ れた場合に、その標識の認知率を向上させるために何ら かの工夫が必要か否かを判断する上で有用である。
(\%)

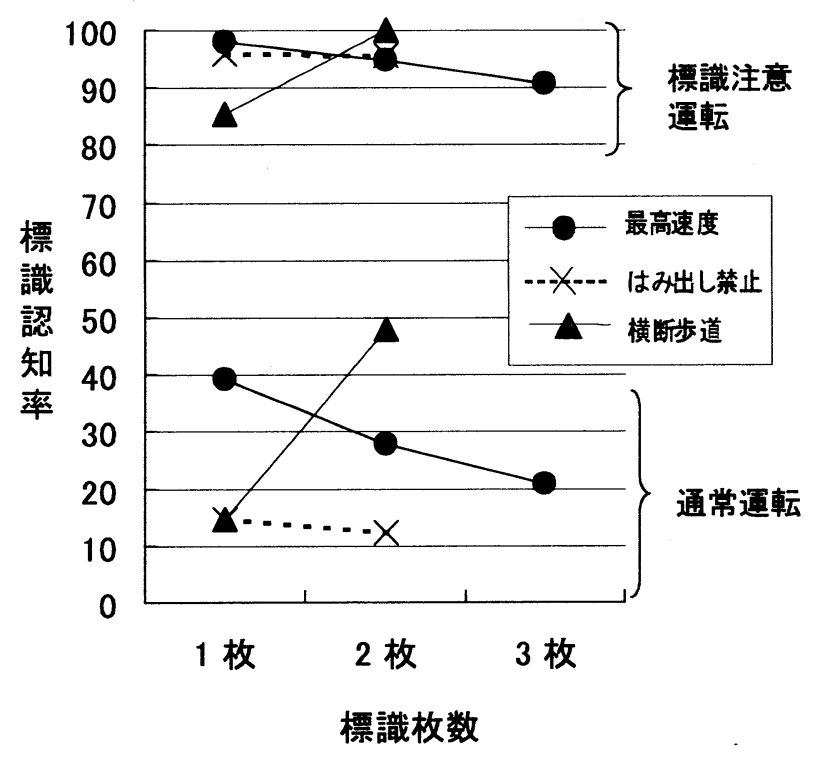

図 8 標識枚数別の認知率

(\%)

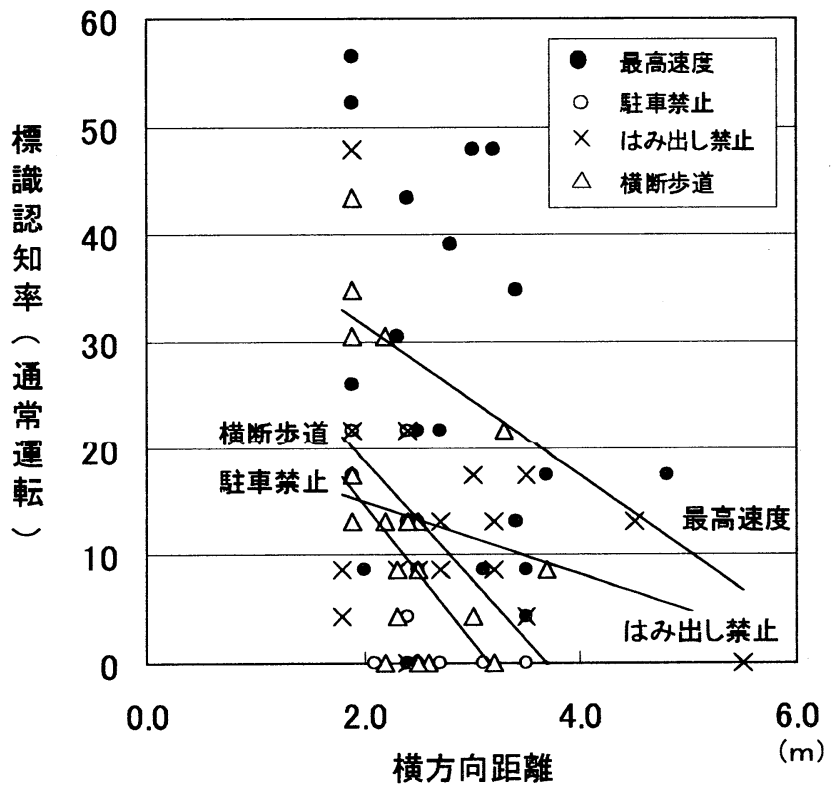

図 9 路側標識の横方向位置と認知率

表 4 回帰分析結果

\begin{tabular}{|c|c|c|c|c|}
\hline \multirow[t]{2}{*}{ 標識の種類 } & \multirow[t]{2}{*}{ 本数 } & \multicolumn{2}{|c|}{$y=a x+b$} & \multirow[t]{2}{*}{ 相関係数 } \\
\hline & & a & $\bar{b}$ & \\
\hline 最高速度 & 20 & -7.1 & 45.8 & 0.094 \\
\hline 駐車禁止 & 18 & -12.8 & 40.2 & 0.414 \\
\hline はみ出し禁止 & 14 & -3.4 & 21.6 & 0.084 \\
\hline 横断歩道 & 20 & -11.2 & $\overline{41.2}$ & 0.207 \\
\hline
\end{tabular}

$x$ : 横方向距離、 $y$ : 標識認知率 
図10は、表 1 に示した道路タイプごとに認知率を示 した図である。道路タイプ別標識本数を表 5 に示す。

まず、通常運転をみると、最高速度標識とはみ出し禁 止標識で道路 $a, b, c$ の順に認知率が低下していることが 示されている。また、道路 $\mathrm{b}$ と $\mathrm{c}$ の比較では、いずれの 標識も道路bに比べて道路cの認知率が低くなっている。 表 1 に示したように道路 a は住宅地内の道路で、対向車 や歩行者はほとんど見られず、前車に追従して走行する こともまれである。道路 b は、沿道が街路樹の広幅員道 路で、交通量はやや多いものの交差方向からの車や横断 歩行者は比較的少ない。この道路では対向車にしばしば 出会うが道路 c ほど頻繁ではない。道路 c は、典型的な 地方部幹線道路で走行中は前車に追従することが多く対 向車にも頻繁に遭遇する。また、交差点も多く沿道には 様々な商店の看板類が多数設置されている。

以上のことから、運転中に注意を向けるべき対象物は、 道路 a で最も少なく、道路 b, c の順で多くなることがわ かる。したがって、図 10 の結果は、通常運転時の標識 認知率は、運転時に摂取すべき情報量の増加にともなっ て低下することを示唆していると考えられる。

次に、標識注意運転では、通常運転と比べると道路夕 イプ別の認知率の相違が明確でない。これは、本実験コ ースはいずれも片側 1 車線であり、意識的に標識に注意 を向けても運転に支障が生じない程度の交通状況であっ たためと考えられる。交通量が多く走行速度も高い多車 線道路などでは常に標識に注意を集中して運転すること が安全運転上困難な場合がある。このような状況では、 標識注意運転においても交通状況の複雑さに応じて標識 認知率に相違が生じる可能性が考えられる。

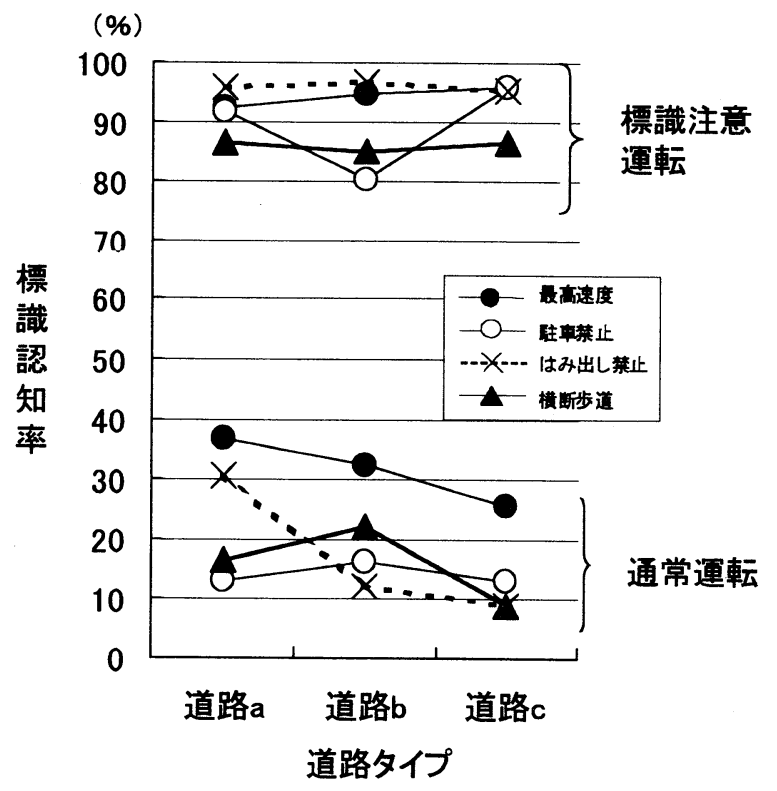

図 10 道路タイプ別の標識認知率

\section{表 5 道路タイプ別の標識本数}

\begin{tabular}{|c|c|c|c|}
\hline \multirow[b]{2}{*}{ 標識種類 } & \multicolumn{3}{|c|}{ 標識本数 } \\
\hline & 道路a & 道路b & 道路c \\
\hline 最高速度 & 5 & 7 & 15 \\
\hline 駐車禁止 & $\overline{6}$ & 16 & $\overline{3}$ \\
\hline はみ出し禁止 & 3 & 4 & 13 \\
\hline 横断歩道 & 14 & 15 & 12 \\
\hline
\end{tabular}

\section{（5）各要因が標識認知に及ぼす相対的影響度}

\section{（a）検討対象とした要因}

前節では、個々の要因別に標識認知率との関連性を検 討した。本節では、各要因が標識認知に及ぼす影響度を 比較する。そして、標識認知率を向上させるためには、 実際に標識を設置する際にどの要因を優先的に考慮すべ きか、を明らかにする。

検討の対象とした要因としては、次の 5 要因を選んだ。 (1)設置方式（路側式かオーバーハング式か）

(2) 1 本の柱の設置されている標識枚数

(3)設置位置 (道路の左側か右側か)

(4)右左折してから標識設置位置までの距離（屈折距離、

$50 \mathrm{~m}$ 未満と $50 \mathrm{~m}$ 以上に区分)

(5)道路タイプ(表 1 の3タイプ)

前節で検討した要因のうち、横方向距離を除外し、屈 折距離を新たに加えた。横方向位置を検討要因から除い た理由は、前述したように、認知率との関連性が低いこ とが判明したためである。また、屈折距離を新たな検討 要因として追加した理由は、一般に運転者は交差点での 右左折中や右左折直後は、他の車、歩行者、進行方向の 交通状況等に注意を向ける行動をとるため、右左折直後 に視認しなければならないような位置にある標識の認知 率は低いことが予想されるからである。ここで、右左折 直後とそれ以外を区分する境界值として $50 \mathrm{~m}$ 用いたが、 厳密には、右左折時に特有な注視行動が右左折終了後ど の程度継続するかについての研究結果を踏まえて決定す る必要がある。しかしながら、このような課題を扱つた 研究事例を見出すことができなかったため、今回は便宜 的に 50mを採用した。

\section{（b）影響度評価の方法}

影響度評価には数量化 II類を用いた。外的基準は、標 識認知率の高低とした。認知率高低の判断は、個々の標 識の認知率を基に、認知率が高い群、中程度の群、低い 群にグループ化することで行った。具体的には、認知率 の累積相対頻度分布が $33.3 \%$ 、及び $66.7 \%$ に対応する標 識認知率をそれぞれ $11, \mathrm{p} 2$ とし、認知率が 1 以下の標 識を認知率が低い群、認知率が $\mathrm{p} 1$ より大きく $\mathrm{p} 2$ より小 さい標識を認知率が中程度の群、認知率が $\mathrm{p} 2$ 以上の標識 
を認知率が高い群とした。そして、上記の 5 要因を用い て、認知率が高い群と低い群を判別することを試みた。

\section{(c) 分析結果}

数量化II類による分析は、まず、通常運転のデー夕を 用いて標識の種類別に行った。分析対象とした標識は、 総設置本数が 20 本以上の最高速度、駐車禁止、追い越し 禁止、横断歩道の 4 種類の標識である。

最初に、前項で述べた方法によって標識を認知率の低 い群、高い群に分類した。分類結果を表 6 に示す。続い て、認知率の高低を外的基準とし、（a)に示した 5 要因を 説明変数とする数量化II類の分析を行った。

表 7 に分析結果を示す。同表中に示した要因別のレン ジは各要因の判別への寄与度を表すことから、例えば最 高速度標識では、標識枚数、道路タイプ、設置方式の順 で認知率の高低に大きな影響を及ぼしていることがわか る。全体的に見ると、設置方式が標識の種類にかかわら ず認知率の高低に比較的大きな影響を及ぼすことが示さ れている。また、設置場所の左右別についても、駐車禁 止標識と横断歩道標識のデー夕のみであるが、認知率の 高低判別への寄与度が大きい。したがって、通常運転時 の認知率を向上させるためには、オーバーハング型標識 を用いることが望ましく、道路の右側に標識を設置する ことは避けた方がよいと言える。

標識注意運転では、図 5 に示すように過半数の標識で 認知率は $100 \%$ であった。このため、通常運転と同様な 方法で標識の種類別に認知率の高い群と低い群にグルー プ化すると、低い群で十分なサンプル数を得ることがで きなかった。そこで、規制及び警戒標識全体（計 145 本） に着目し、認知率 $100 \%$ の群を認知率が高い群、認知率 50\%以下の群を認知率が低い群に分類した。そして、認 知率の高低を外的基準、(a)に示した 5 要因を説明変数と する数量化II類の分析を行った。

標識をグループ化した結果を表 8 に示す。また、数量 化II類の分析結果を表 9 に示す。表 9 より、標識注意運 転時の認知率に最も大きな影響を及ぼしているのは設置 位置の右左別であり、次いで屈折距離であることがわか る。したがって、標識注意運転時の認知率を低下させな いためには、標識を道路の右側に設置したり右左折した 直後に視認しなければならないような位置に標識を設置 することはできる限り避けることが望ましいと言える。

\section{表 6 標識認知率に基づくグループ化（通常運転）}

\begin{tabular}{|c|c|c|c|c|c|c|}
\hline \multirow[t]{3}{*}{ 標識 } & \multicolumn{3}{|c|}{ 認知垒：低い群 } & \multicolumn{3}{|c|}{ 諰知率:高い群 } \\
\hline & 本数 & 境界值 & 平均 & 本数 & 境界値 & 平均 \\
\hline & & $\mathrm{p} 1(\%)$ & 認知率\% & & $\mathrm{p} 2(\%)$ & 認知率\% \\
\hline 最高速度 & 10 & 17.4 & 9.1 & 9 & 43.5 & 51.7 \\
\hline 駐車禁止 & 10 & 8.7 & 2.6 & 9 & 21.7 & 28.0 \\
\hline はみ出し学止 & 10 & 8.7 & 5.2 & 7 & 17.4 & 23.0 \\
\hline 横断歩道 & 20 & 8.7 & 5.0 & 14 & 17.5 & 33.9 \\
\hline
\end{tabular}

表 7 数量化 II 類の分析結果 (通常運転)

\begin{tabular}{|c|c|c|c|c|c|}
\hline & \multirow[b]{2}{*}{ 標識 } & \multirow[b]{2}{*}{$\begin{array}{l}\text { 最高 } \\
\text { 速度 }\end{array}$} & \multicolumn{3}{|c|}{ スコア } \\
\hline & & & $\begin{array}{l}\text { 駐車 } \\
\text { 禁止 }\end{array}$ & $\begin{array}{l}\text { はみ出 } \\
\text { し禁止 }\end{array}$ & $\begin{array}{l}\text { 横断 } \\
\text { 歩道 }\end{array}$ \\
\hline 要因 & カテゴリー & & & & \\
\hline \multirow{3}{*}{ 設置方式 } & ハング & 0.94 & 1.40 & 2.20 & 0.73 \\
\hline & 路側式 & -0.34 & -1.02 & -0.29 & -0.83 \\
\hline & レンジ & 1.28 & 2.42 & 2.50 & 1.56 \\
\hline \multirow[t]{4}{*}{ 枚数 } & 1枚 & 0.80 & 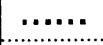 & -0.23 & -0.02 \\
\hline & 2 枚 & 0.09 & ....... & 0.05 & 0.25 \\
\hline & 3枚 & -1.06 & $\cdots \cdots \cdot$ & $\cdots \cdots \cdot$ & $\ldots \ldots$. \\
\hline & レンジ & 1.86 & $\ldots \ldots$ & 0.28 & 0.26 \\
\hline \multirow[t]{3}{*}{ 右左別 } & 左 & $\cdots \cdots$ & 0.13 & $\cdots \cdots$ & 0.60 \\
\hline & 右 & ....... & -2.29 & ....... & -1.45 \\
\hline & レンジ & $\ldots \ldots$. & 2.42 & $\ldots \ldots$ & 2.05 \\
\hline \multirow[t]{3}{*}{ 蚛折距離 } & $50 \mathrm{~m}$ 下 & 0.98 & 0.00 & ........... & ............. \\
\hline & $50 \mathrm{~m}$ 未満 & -0.18 & 0.00 & ...... & ...... \\
\hline & レンジ & \begin{tabular}{|l|}
1.16 \\
\end{tabular} & 0.00 & $\ldots . .$. & $\ldots . .$. \\
\hline \multirow[t]{4}{*}{ 道路タイプ } & 道路a & 1.07 & 0.97 & 1.71 & 0.64 \\
\hline & 道路b & 0.35 & -0.45 & 0.46 & 0.07 \\
\hline & 道路C & -0.53 & 0.97 & -0.51 & -0.61 \\
\hline & レンジ & 1.61 & 1.41 & 2.22 & 1.25 \\
\hline 相関比 & & 0.35 & 0.50 & 0.66 & 0.52 \\
\hline
\end{tabular}

表 8 標識認知率に基づくグループ化（標識注意運転）

\begin{tabular}{|c|c|c|c|c|}
\hline \multirow[t]{2}{*}{ 標識 } & \multirow{2}{*}{\multicolumn{2}{|c|}{ 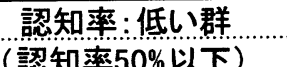 }} & \multicolumn{2}{|c|}{ 認知率:高い群 } \\
\hline & & & （認知率 & $100 \%)$ \\
\hline & 本数 & $\begin{array}{l}\text { 平均 } \\
\text { 認知率\% }\end{array}$ & 本数 & \begin{tabular}{|l|} 
平均 \\
認知县\%
\end{tabular} \\
\hline 全規制警戒 & & & & \\
\hline 標識 & 19 & 33.6 & 89 & 100 \\
\hline
\end{tabular}

表 9 数量化 11 類の分析結果（通常運転）

\begin{tabular}{|c|c|c|}
\hline & & スコア \\
\hline & 標識 & 全規制· \\
\hline 要因 & カテゴリー & 警戒標識 \\
\hline \multirow[t]{3}{*}{ 設置方式 } & ハング & 0.35 \\
\hline & 路側式 & -0.15 \\
\hline & レンジ & 0.49 \\
\hline \multirow[t]{4}{*}{ 枚数 } & 1 枚 & -0.14 \\
\hline & 2枚 & 0.23 \\
\hline & 3枚 & 1.31 \\
\hline & レンジ & 1.45 \\
\hline \multirow[t]{3}{*}{ 右左别 } & 左 & 0.23 \\
\hline & 右 & -2.56 \\
\hline & レンジ & 2.80 \\
\hline \multirow[t]{3}{*}{ 屈折距離 } & $50 \mathrm{~m}$ 以下 & -1.67 \\
\hline & $50 \mathrm{~m}$ 末満 & 0.13 \\
\hline & レンジ & 1.81 \\
\hline \multirow[t]{4}{*}{ 道路タイプ } & 道路a & -0.28 \\
\hline & 道路b & -0.13 \\
\hline & 道路 C & 0.23 \\
\hline & レンジ & 0.51 \\
\hline & & 0.38 \\
\hline
\end{tabular}




\section{5.まとめ}

本研究では、運転者の道路標識の認知状況に影響する 要因の分析を通じて、標識のもつ情報を運転者に的確に 伝えるための標識の設置方法について検討した。

実際の道路上に全長約 $14 \mathrm{~km}$ の実験コースを設定し、合 計 31 名（高齢者 16 名、若年者 15 名）の被験者を用 いて走行実験を行った。被験者は運転中の注意の仕方に よって 2 群に分けた。第 1 群は、標識に限らず見たもの すべてを口頭報告するように教示した通常運転グループ であり、第 2 群は、標識に注意して運転し、見つけた 標識のみを口頭報告するように教示した標識注意運転グ ループである。報告内容を分析することにより、個々の 標識の認知率を算出した。そして、主に規制標識に着目 して、その属性（種類、設置方法、設置位置等）と認知 率の関連性を調べた。

その結果、標識認知率は通常運転で 16\% 18\%、標識 注意運転で 84\% 90\%であること、高㱓者と若年者で標 識認知率に大きな差は見られないこと、路側式標識より もオーバーハング式標識の方が認知率が高いこと、路側 標識の横方向距離は認知率に大きな影響を及ぼさないこ と、交通量が多く運転中に摂取すべき情報量が多い道路 ほど標識認知率が低下することなどが明らかとなった。 また、各要因が標識認知に及ぼす相対的影響度を数量化 II類を用いて分析した結果、通常運転時の認知率を向上 させるためには特にオーバーハング標識を用いるのが望 ましいこと、標識注意運転時の認知率を低下させないた めには標識の右側設置を避ける必要があること等が明ら かとなった。

本研究では、個別の規制標識に着目して調査を行った が、実際の交通管理業務では、標識の設置間隔を工夫し たり標識と標示を併用することによって運転者の規制情 報の見落としを防ぐ対策が採られる。標識の設置間隔や 標示との併用方法は、個々の標識の認知状況に関する検 討結果をべースにして決められるものであるので、本研 究で得られた標識認知状況に関する知見は、今後、標識 の最適設置間隔や標示との具体的併用方法を明らかにす るための研究に役立つものと考えられる。

今後の課題としては以下の点が挙げられる。本研究で は、実際に標識を設置する立場から設置方法に関する知
見を得ることをねらいとしたため、時々刻々と変化する 周囲の交通状況(対向車の接近状況、横断歩行者の有無、 前車との車間距離等）が標識認知率に及ぼす影響につい ては詳細な分析は行っていない。運転中には、対向車、 横断歩行者、駐車車両、細街路から進入しようとする車 等にかなりの注意が向けられる。したがって、ある標識 の認知率は、運転者がその標識の近くを通過した時点の 交通状況（対向車の接近状況、横断歩行者の有無、前車 との距離等）にも影響されると考えられる。今後の課題 として、これら周囲の交通環境が標識認知に及ぼす影響 を詳細に検討することが挙げられる。また、本研究は、 昼間時の標識の認知状況について検討を行ったが、標識 は昼間だけでなく夜間にも交通安全上重要な役割を果た す。特に、高齢者は夜間の視機能が低下する傾向がある ので、今後は、夜間における標識の認知を向上させるた めの設置方法についても検討する必要がある。

\section{参考文献}

1）松田隆夫 : 視知覚、培風館, 1995.

2）蓮花一己:ドライバーの視覚的注意に及ぼす運転経験 の効果、IATSS review, Vol.5, No.3, pp.204-214,1979.

3) Hughes,P.K. and Cole,B.L.: Search and Attention Conspicuity of Road Traffic Control Devices, Australian Road Research Board 14(1), pp. 1-9,1984.

4) Cole,B.L. and Hughes, P.K. A Field Trial of Attention and Search Conspicuity, Human Factors 26(3), pp.299-313, 1984.

5) Hughes,P.K. and Cole,B.L.: What attracts attention when driving?, Ergonomics, Vol.29, No.3,pp.377-391, 1986.

6) Johansson, G. and Rumar,K. : Drivers and Road Signs: A preliminary investigation of the capacity of car drivers to get information from road signs, Ergonomics, Vol.9, pp.57-62, 1966.

7) Johanson, G. and Backlund, F. : Drivers and Road Signs, Ergonomics, Vol.13, No.6, pp.749-759,1970. 8）例えば、三井達郎 : 自発光式道路鋲がカーブにおける 運転行動に及ぼす影響、科警研報告交通編、39巻 1 号、 pp.1-13, 1998.

\section{運転者の規制標識認知に影響する要因に関する研究}

三井達郎、矢野伸裕、木平真

本研究は、運転者の道路標識の認知状況に影響する要因を調査し、標識のもつ情報を運転者に的確に伝え るための標識の設置方法に関して知見を得ることを目的とする。現実の道路上に全長約 $14 \mathrm{~km}$ の実験コース を設定し、合計 31 名（高齢者 16 名、若年者 15 名）の被験者を用いて実走行実験を行った。標識認知状 況の測定は言語報告法を用いて行い、報告内容を分析することにより、個々の標識の認知率を算出した。そ の結果、高齢者と若年者の標識認知率に大きな差は見られないこと、路側式標識よりもオーバーハング式標 識の方が認知率が高いこと、路側標識の横方向距離は認知率に大きな影響を及ぼさないこと、交通量が多く 運転中に摂取すべき情報量が多い道路ほど標識認知率が低下することなどが明らかとなった。 
Factors Affecting Driver Recognition of Regulatory Signs

Tatsuro MITSUI, Nobuhiro YANO, Makoto KIHIRA

The purpose of this paper is to explore the factors that determine conspicuity of regulatory signs, and to investigate how to install regulatory signs to increase the chances of attracting attention. Factors under consideration were types of signs, lateral clearance, location, roadside or overhead signs, the number of plates attached to one post and the road environment. The main results are as follows. The recognition rate for elderly drivers was similar to that of younger drivers. Overhead signs have higher recognition rates than conventional roadside signs. Signs were less conspicuous in arterial roads than in residential roads. The outcome of the quantification method shows that the most effective action to enhance recognition rates is to use overhead signs. 